\title{
Effects of whey, molasses and exogenous enzymes on the ensiling characteristics, nutrient composition and aerobic stability of maize cobs
}

\author{
A.T. Kanengoni ${ }^{1 /}$, B.D. Nkosi ${ }^{1,2}$, M. Chimonyo ${ }^{3}$, B. Ndimba ${ }^{4}$ \& K. Dzama ${ }^{5}$ \\ ${ }^{1}$ ARC-Animal Production Institute, Private Bag X2, Irene, 0062, South Africa \\ ${ }^{2}$ Centre for Sustainable Agriculture and Rural Development, University of Free State P.O. Box 339, \\ Bloemfontein, 9300, South Africa \\ ${ }^{3}$ Discipline of Animal \& Poultry Science, University of KwaZulu-Natal, P. Bag X01, Scottsville, \\ Pietermaritzburg, 3209, South Africa \\ ${ }^{4}$ Agricultural Research Council, Proteomics Research and Services Unit, Infruitec. Nietvoorbij Institute, Department of \\ Biotechnology, University of the Western Cape, Private Bag X17, Bellville, Cape Town, 7535, South Africa \\ ${ }^{5}$ Department of Animal Sciences, Stellenbosch University, Private Bag X1, Matieland, 7602, South Africa
}

(Received 24 August 2014; Accepted 19 February 2016; First published online 4 May 2016)

\begin{abstract}
Copyright resides with the authors in terms of the Creative Commons Attribution 2.5 South African Licence.
See: http://creativecommons.org/licenses/by/2.5/za

Condition of use: The user may copy, distribute, transmit and adapt the work, but must recognise the authors and the South African Journal of Animal Science.
\end{abstract}

\begin{abstract}
The study was conducted to assess the effects of whey, molasses and exogenous enzymes on fermentation, aerobic stability and nutrient composition of ensiled maize cobs. Five treatments were ensiled in $1.5 \mathrm{~L}$ anaerobic glass jars over 32 days, namely i) control (maize cobs without additives (CON); ii) maize cobs with sugarcane molasses only (MOL); iii) MOL and whey (MOW); iv) MOW and exogenous enzyme at $0.5 \mathrm{~g} / \mathrm{kg}$ maize cob mixture (ENZ1) and v) MOW and exogenous enzyme at $1 \mathrm{~g} / \mathrm{kg}$ maize cob mixture (ENZ2). There was a day effect on gross energy (GE) for CON, MOL, ENZ1 and ENZ2 and none for MOW. There was a day effect in ADF for MOL, ENZ1 and ENZ2 and none for CON and MOW. There was lower dry matter (DM) on day 32 compared with day 0 for all treatments. There were treatment effects for GE, crude protein (CP), ash, ether extract, amylase-treated neutral detergent fibre and acid detergent fibre (ADF). On day 32, the neutral detergent fibre (NDF) and ADF concentrations in CON were higher than in MOL, MOW and ENZ2. At day 32, CON silage pH (4.2) was lower than the pH values of ENZ1 (4.5) and ENZ2 (4.6) silages. Acetic acid levels were higher in ENZ1 than ENZ2 silages. Ammonia nitrogen $\left(\mathrm{NH}_{3}-\mathrm{N}\right)$ levels averaged $25 \pm 6.6 \mathrm{~g} \mathrm{NH}_{3}-\mathrm{N} / \mathrm{kg}$ total nitrogen, which is indicative of satisfactory ensiling. The MOL, ENZ1 and ENZ2 silages produced more carbon dioxide than CON and MOW silages. The addition of molasses and whey did not improve the nutritive quality of the maize cobs after ensiling. Ensiling maize cobs with molasses, whey and exogenous enzymes resulted in lower DM and fibre levels in the maize cobs, which could enhance intake and digestibility of nutrients when offered to pigs as a component of a balanced diet. Further investigations using higher concentrations of whey and molasses are warranted to improve the energy and protein composition of the maize cobs.
\end{abstract}

Keywords: Exogenous enzymes, fibre, fermentation, volatile fatty acids

\# Corresponding author: Arnoldk@arc.agric.za

\section{Introduction}

Maize cobs have been included in pig diets up to concentrations of $200 \mathrm{~g} / \mathrm{kg}$ in efforts to offset high feed costs (Ndindana et al., 2002; Kanengoni et al., 2004). Nonetheless, the use of maize cobs as a feed ingredient in pig nutrition is limited by high fibre (930 g neutral detergent fibre (NDF)/kg dry matter (DM); 573 $\mathrm{g}$ acid detergent fibre (ADF)/kg DM) and low protein (35.5 g crude protein (CP)/kg DM) contents (Viljoen, 1993; Ndindana et al., 2002; Kanengoni et al., 2004). High dietary fibre increases the rate of feed passage in the pig gut, and sequestrates nutrients in the fibre matrix, reducing their digestion (Stanogias \& Pearce, 1985; Fevrier et al., 1992). Fibre levels in maize cobs should be reduced to improve their nutritive contribution to pig diets. Fermentation and the use of exogenous enzymes and acids have been reported to reduce fibre content of maize cobs (Latif \& Rajoka, 2001; Le Gall et al., 2009; Urriola et al., 2010; Zhang et al., 2010a). However, the use of acids to decrease fibre is unattractive because of safety, and environmental and economic concerns. Ensiling has reduced fibre content in forages (Gatel et al., 1988; Khan et al., 2006; Rezaei et al., 2009) and could therefore improve the value of maize cobs as a pig feed resource. Maize cobs 
are difficult to ensile owing to the high DM content and low levels of water-soluble carbohydrate (WSC) concentrations required for lactic acid production (McDonald et al., 1991). Khan et al. (2006) ensiled maize cobs (913 g/kg DM) with acidified molasses and urea, and reported improved nutrient digestibility and nitrogen utilization in buffaloes. Similar innovative applications of silage additives could enhance the value of maize cobs as a pig feed ingredient. Sugarcane molasses contains substantial amounts of WSC, while fresh cheese whey contains WSC, soluble protein and some lactic acid bacteria (LAB), which could benefit the ensiling process and boost the nutritive value of maize cobs by increasing energy, protein and minerals (Khan et al., 2006; Bautista-Trujillo et al., 2009; Repetto et al., 2011). Whey is normally thrown away and sugarcane molasses is cheaply available, making them attractive resources for smallholder farmers.

Exogenous enzymes are added to silage to partially degrade fibre to fermentable WSC for use by LAB, which cannot use fibre as an energy source (Eun \& Beauchemin, 2007). However, exogenous enzyme activities against structural carbohydrates may be inhibited in the presence of LAB (Stokes, 1992; Xing et al., 2009). Xylans comprise up to $50 \%$ of the hemicelluloses in maize cobs (Ebringerová \& Heinze, 2000; Vázquez et al., 2006). It was hypothesized that the nutritive value of maize cobs as a feed ingredient for pigs could be improved through degradation of xylans by commercially available xylanases and the addition of molasses and whey under anaerobic conditions. The objective of this study was therefore to assess the effects of adding sugarcane molasses, fresh cheese whey and exogenous enzymes on the fermentability, nutrient composition and aerobic stability of maize cobs.

\section{Materials and Methods}

Maize cobs (920 g/kg DM) were collected from the Agricultural Research Council - Animal Production Institute fields (ARC-API, Irene, Gauteng, South Africa), and ground with a hammer mill (M24, Drosky, Alberton, Johannesburg) to pass through a 5-mm sieve. Sugarcane molasses syrup was obtained from Obaro $\AA$, a local dealer, and fresh whey from the cheese factory at ARC-Irene. Porzyme $9302 \AA$, an enzyme containing endo-1,4-beta-xylanase activity of $8000 \mathrm{U} / \mathrm{g}$, was obtained from Danisco Ltd (Tsessebe Crescent, Midrand, South Africa). Sugarcane molasses syrup was diluted with warm water at a ratio of $1: 2$ (resulting in a $33 \%$ molasses solution) and sprayed evenly over the maize cobs at a rate of $100 \mathrm{~mL} / \mathrm{kg}$. Distilled water was added to achieve a moisture content of $600 \mathrm{~g} / \mathrm{kg}$ maize cobs. Fresh whey was added at a rate of 50 $\mathrm{mL} / \mathrm{kg}$ maize cob. Two levels ( 0.5 and $1 \mathrm{~g} / \mathrm{kg}$ maize cob) of the enzyme were included in two treatments. The treatments were i) control (maize cobs without additive (CON)); ii) maize cobs with $33 \%$ sugarcane molasses solution only (MOL), iii) $\mathrm{MOL}$ and whey $(100 \mathrm{~mL}$ of $33 \%$ molasses solution and $50 \mathrm{~mL}$ whey per $\mathrm{kg}$ maize cobs (MOW); iv) MOW with exogenous enzyme at $0.5 \mathrm{~g} / \mathrm{kg}$ maize cob mixture (ENZ1); and v) MOW with exogenous enzyme at $1 \mathrm{~g} / \mathrm{kg}$ maize cob mixture (ENZ2). These mixtures were ensiled in $1.5 \mathrm{~L}$ anaerobic glass jars (J. Weck, GmBH u. Co., Wehr-Oflingen, Germany) equipped with lids, rubber rings and steel clamps to enable gas release and keep the jars airtight. Jars were stored out of sunlight and kept at 24 - 28 ${ }^{\circ} \mathrm{C}$. Each jar was filled with approximately $1116 \pm 5.8 \mathrm{~g}$ (wet weight) maize cobs without a headspace, and a packing density of $744.2 \pm 3.86 \mathrm{~kg} / \mathrm{m}^{3}$ was obtained. Three jars per treatment were opened on days $0,1,4$, 15 and 32 of ensiling, and sampled to determine $\mathrm{pH}$ and DM. Further, analyses for gross energy (GE), CP, EE, NDF and ADF were done on samples collected on days 0,15 and 32 . Analyses for WSC, volatile fatty acids (VFAs), lactic acid (LA) and ammonia-N $\left(\mathrm{NH}_{3}-\mathrm{N}\right)$ were done on samples collected on days 0 and 32 . Representative silage samples from day 32 of all treatments were subjected to an aerobic stability test, in which samples were exposed to air for five days and carbon dioxide $\left(\mathrm{CO}_{2}\right)$ production and $\mathrm{pH}$ were determined following the procedure of Ashbell et al. (1991).

A $40 \mathrm{~g}$ sample of ensiled material was collected from each jar and mixed with $360 \mathrm{~mL}$ distilled water in a stomacher bag, blended, and left for 24 hours at $10^{\circ} \mathrm{C}$ (Suzuki \& Lund, 1980). It was then homogenized for 4 min and filtered through a Whatman No. 4 filter paper (G.I.C. Scientific, Midrand, South Africa). The extract was then used to determine pH, WSC (according to Dubois et al. 1956), LA (as done by Pryce, 1969), VFAs (according to Suzuki \& Lund, 1980) and $\mathrm{NH}_{3}-\mathrm{N}$ (AOAC, 1990; ID 941.04). The DM of silage was determined by drying the samples at $60{ }^{\circ} \mathrm{C}$ until a constant mass was achieved. This value was corrected for loss of volatiles with the equation of Porter \& Murray (2001). Dry samples were ground to pass through a 1-mm screen (Wiley mill, Standard Model 3, Arthur H. Thomas Co., Philadelphia, Phil, USA) prior to being used for chemical analyses. The aNDF was determined following the procedures of Van Soest et al. (1991) using heat stable a-amylase, and the ADF was determined with Fibertec System equipment (Tecator LTD., Thornbury, Bristol, UK). Separate samples were used for ADF and aNDF analysis and both included residual ash. Crude protein (ID 968.06), ash (ID 942.05) and EE (ID 963.15) were determined according to the procedures of AOAC (1990). Gross energy was determined with bomb calorimetry (MS-1000 modular calorimeter, Energy Instrumentation, Centurion, South Africa).

Data for fermentation, aerobic stability and nutrient composition of the silage were analysed for effects of treatment using GLM procedures of SAS (2012). All data were tested for normality and homogeneity. 
Comparisons were made to the $95 \%$ significance level and tendencies were considered at $0.05<P \leq 0.10$. $\mathrm{NH}_{3}-\mathrm{N}$ and lactic acid data were inverse transformed to achieve normality. The model used to compare the data was;

$$
Y_{i j k}=\mu+T_{i}+D_{j}+(T * D)_{i j}+\varepsilon_{i j k}
$$

where $Y_{i j}$ is the dependent variable, $\mu$ is the overall mean, $T$ is the treatment effect $(i=C O N, M O L, M O W$, ENZ1, ENZ2), D is the day of ensiling $(0,32), T x D$ is the interaction of treatment and day and $\varepsilon_{\mathrm{ij}}$ is the experimental error. The PDIFF statistic of SAS (2012) was used to separate the treatment means.

\section{Results}

Nutrient composition of maize cobs pre-ensiling and at day 32 are shown in Table 1. There were day by treatment interactions for GE and ADF $(P<0.05)$ and a tendency for aNDF $(P=0.057)$. There was a day effect on GE for CON, MOL, ENZ1 and ENZ2 $(P<0.05)$ and none for MOW. There was a day effect in ADF for MOL, ENZ1 and ENZ2 $(P<0.05)$ and none for CON and MOW. Dry matter was lower $(P<0.05)$ on day 32 compared with day 0 for all treatments. Treatment had a significant $(P<0.05)$ effect on GE, CP, ash, EE, aNDF and ADF $(P<0.05)$. On day 32 the NDF and ADF concentrations in CON were higher than in MOL, MOW and ENZ2.

Table 1 Means of nutrient composition of maize cobs at days 0 and $32(n=3)$

\begin{tabular}{|c|c|c|c|c|c|c|c|}
\hline \multirow{3}{*}{$\begin{array}{l}\text { Treatments } \\
\text { (Trt) }\end{array}$} & \multirow{3}{*}{$\begin{array}{c}\text { DM } \\
\text { g/kg }\end{array}$} & \multicolumn{6}{|c|}{ Nutrients } \\
\hline & & \multirow{2}{*}{$\begin{array}{c}\text { GE } \\
\mathrm{MJ} / \mathrm{kg} \text { DM }\end{array}$} & CP & Ash & $\mathrm{EE}$ & aNDF & ADF \\
\hline & & & \multicolumn{5}{|c|}{ g/kg DM } \\
\hline \multicolumn{8}{|l|}{ Day 0} \\
\hline CON & $583^{b}$ & $18.2^{\mathrm{ef}}$ & $31^{\mathrm{ab}}$ & $17.1^{\mathrm{a}}$ & $5.1^{\mathrm{ab}}$ & $825^{d}$ & $455^{\mathrm{def}}$ \\
\hline MOL & $557^{\mathrm{b}}$ & $18.0^{\mathrm{b}}$ & $32^{\mathrm{ab}}$ & $30.4^{\mathrm{bc}}$ & $5.8^{\mathrm{bc}}$ & $753^{b}$ & $409^{b}$ \\
\hline MOW & $537^{b}$ & $18.0^{\mathrm{bc}}$ & $34^{\mathrm{abc}}$ & $28.3^{\mathrm{b}}$ & $5.6^{\mathrm{abc}}$ & $774^{\mathrm{bc}}$ & $431^{\text {bcde }}$ \\
\hline ENZ1 & $581^{b}$ & $18.0^{\mathrm{bc}}$ & $33^{\mathrm{ab}}$ & $32.6^{\mathrm{bc}}$ & $5.1^{\mathrm{ab}}$ & $764^{\mathrm{bc}}$ & $420^{b c}$ \\
\hline ENZ2 & $578^{\mathrm{b}}$ & $17.6^{\mathrm{a}}$ & $40^{c}$ & $33.4^{\mathrm{c}}$ & $6.0^{c}$ & $717^{\mathrm{a}}$ & $385^{a}$ \\
\hline \multicolumn{8}{|l|}{ Day 32} \\
\hline CON & $413^{a}$ & $18.4^{g} \pm$ & $30^{\mathrm{a}}$ & $17.8^{\mathrm{a}}$ & $4.7^{\mathrm{a}}$ & $828^{d}$ & $465^{f}$ \\
\hline MOL & $437^{\mathrm{a}}$ & $18.2^{f} \pm$ & $37^{\mathrm{bc}}$ & $31.8^{\mathrm{bcd}}$ & $5.5^{\mathrm{abc}}$ & $790^{\circ}$ & $440^{\text {cde }}$ \\
\hline MOW & $445^{\mathrm{a}}$ & $18.1^{\text {cde }} \pm$ & $35.7^{\mathrm{bc}}$ & $30.2^{\mathrm{bc}}$ & $6.1^{c}$ & $768^{\mathrm{bc}}$ & $425^{\mathrm{bc}}$ \\
\hline ENZ1 & $435^{a}$ & $18.2^{\mathrm{def}_{ \pm}}$ & $32^{\mathrm{ab}}$ & $30.0^{\mathrm{bc}}$ & $5.2^{\mathrm{abc}}$ & $798^{\mathrm{cd}}$ & $455^{\mathrm{ef}}$ \\
\hline ENZ2 & $436^{a}$ & $18.1^{\mathrm{bcd}} \pm$ & $37^{\mathrm{bc}}$ & $33.0^{c}$ & $5.7^{\mathrm{bc}}$ & $788^{\mathrm{bc}}$ & $436^{\text {bcde }}$ \\
\hline SEM & 16.0 & 0.04 & 1.7 & 1.27 & 0.33 & 12.7 & 8.7 \\
\hline \multicolumn{8}{|l|}{$P$-values } \\
\hline Trt & 0.806 & $<.0001$ & 0.011 & $<.0001$ & 0.019 & 0.0002 & 0.0003 \\
\hline Day (D) & $<.0001$ & $<.0001$ & 0.851 & 0.716 & 0.742 & 0.002 & 0.0002 \\
\hline Trt $\times D$ & 0.190 & 0.002 & 0.379 & 0.591 & 0.604 & 0.057 & 0.034 \\
\hline
\end{tabular}

DM: dry matter; GE: gross energy; CP: crude protein; EE: ether extract; aNDF: amylase treated neutral detergent fibre; ADF: acid detergent fibre.

CON (control, maize cobs with no additives); MOL (maize cobs with 33\% molasses solution only); MOW (maize cobs with 33\% molasses and whey); ENZ1 (maize cobs with molasses, whey and $0.5 \mathrm{~g} / \mathrm{kg}$ enzyme); ENZ2 (maize cobs with molasses, whey and $1 \mathrm{~g} / \mathrm{kg}$ enzyme).

SEM: standard error of mean.

Changes in $\mathrm{pH}$ of ensiled maize cobs are shown in Figure 1. Control silage $\mathrm{pH}$ decreased rapidly from 6.3 on day 0 to 4.1 on day 15 at a higher rate than in MOL (6.0 to 4.9), MOW (6.1 to 4.7), ENZ1 (6.1 to 5.1) and ENZ2 (6.2 to 5.2) silages. At day 32, CON silage pH (4.2) was lower than the pH values of ENZ1 (4.5; $P$ $<0.05)$ and ENZ2 (4.6; $P<0.05)$ silages. Lactic acid (LA) and acetic acid (AA) and $\mathrm{NH}_{3}-\mathrm{N}$ concentrations in the silages after 32 days are shown in Table 2. Butyric acid concentrations were not detectable at 32 days. 
There were no differences in LA and AA concentrations among all the treatments. Ammonia nitrogen $\left(\mathrm{NH}_{3}-\mathrm{N}\right)$ concentrations averaged $25 \pm 6.6 \mathrm{~g} \mathrm{NH}_{3}-\mathrm{N} / \mathrm{kg}$ total nitrogen (TN). Ammonia-N levels were higher $(P$ $<0.05)$ in MOW $(27.3 \mathrm{~g} / \mathrm{kg} \mathrm{TN})$ than in MOL $(18.4 \mathrm{~g} / \mathrm{kg} \mathrm{TN})$ and ENZ2 (16.5 g/kg TN) silages.

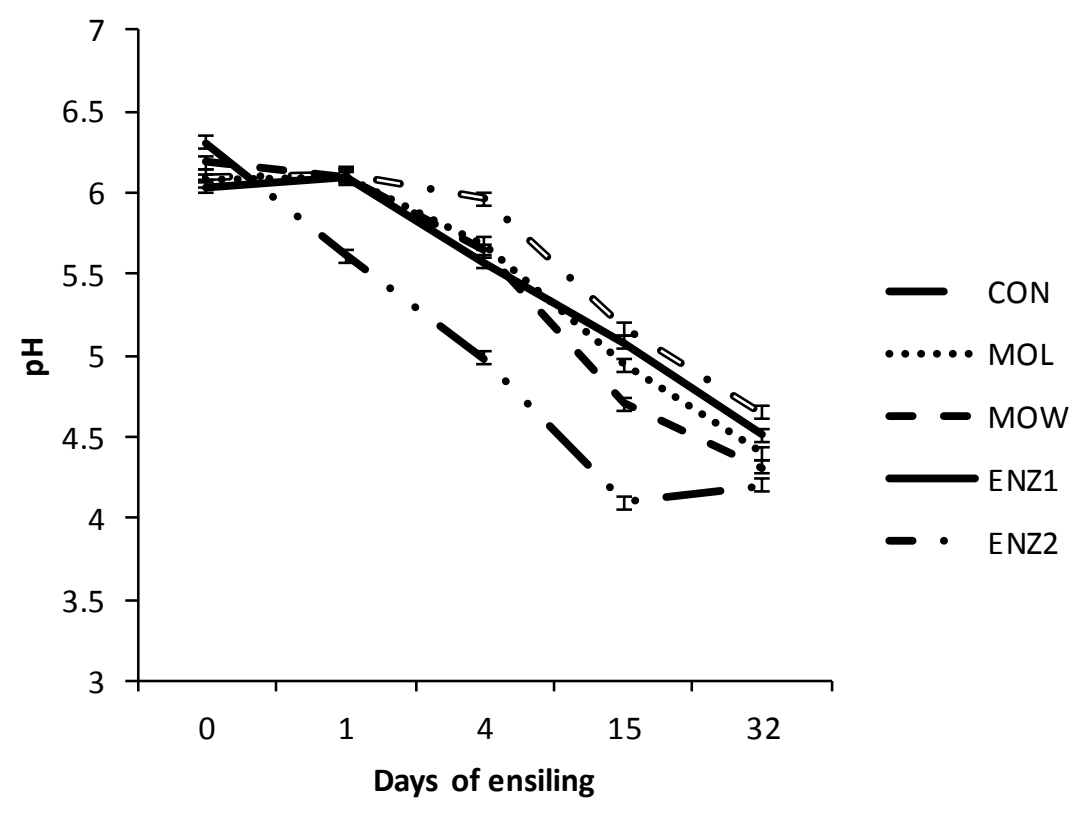

Figure 1 Changes in $\mathrm{pH}$ of ensiled maize cobs treated with or without additives.

Table 2 Lactic and acetic acid concentrations ( $\mathrm{g} / \mathrm{kg}$ dry matter) and ammonia nitrogen ( $\mathrm{g} / \mathrm{kg}$ total nitrogen of maize cobs silage with or without additives after 32 days $(n=3)$

\begin{tabular}{|c|c|c|c|}
\hline \multirow{2}{*}{ Treatment $^{b}$} & \multicolumn{3}{|c|}{ Parameters $^{\mathrm{a}}$} \\
\hline & AA g/kg DM & LA g/kg DM & $\mathrm{NH}_{3}-\mathrm{N}$ g/kg TN \\
\hline CON & 27.4 & 1.1 & $23.1^{\mathrm{bc}}$ \\
\hline MOL & 35.8 & 0.9 & $18.4^{\mathrm{ab}}$ \\
\hline MOW & 36.9 & 1.0 & $27.3^{c}$ \\
\hline ENZ1 & 33.5 & 1.0 & $26.7^{\mathrm{c}}$ \\
\hline ENZ2 & 25.8 & 0.8 & $16.5^{\mathrm{a}}$ \\
\hline SEM & 4.13 & 0.10 & 1.60 \\
\hline$P$-values & 0.337 & 0.289 & 0.016 \\
\hline
\end{tabular}

a LA: lactic acid; AA: acetic acid; $\mathrm{NH}_{3}-\mathrm{N}$ : ammonia nitrogen ( $\mathrm{g} / \mathrm{kg}$ total nitrogen (TN)).

${ }^{\mathrm{b}} \mathrm{CON}$ (control, maize cobs with no additives); MOL (maize cobs with $33 \%$ molasses solution only); MOW (maize cobs with $33 \%$ molasses solution and whey); ENZ1 (maize cobs with $33 \%$ molasses solution, whey and enzyme at $0.5 \mathrm{~g} / \mathrm{kg}$ ); ENZ2 (maize cobs with 33\% molasses solution, whey and enzyme at $1 \mathrm{~g} / \mathrm{kg}$ ): SEM: standard error of mean. The water-soluble carbohydrate (WSC) concentrations at day 0 were: $\mathrm{CON}=8.2 \mathrm{~g} / \mathrm{kg} \mathrm{DM} ; \mathrm{MOL}=30 \mathrm{~g} / \mathrm{kg} \mathrm{DM}$; MOW = $43.9 \mathrm{~g} / \mathrm{kg} \mathrm{DM;} \mathrm{ENZ1} \mathrm{=} 42.9 \mathrm{~g} / \mathrm{kg}$ DM and ENZ2 = $44.2 \mathrm{~g} / \mathrm{kg}$ DM.

The results of the aerobic stability test of the maize cob silages are shown in Table 3. There were no differences in $\mathrm{pH}$ among the silages on day 36. The $\mathrm{MOL}$, ENZ1 and ENZ2 silages produced more $\mathrm{CO}_{2}$ than CON and MOW $(P<0.05)$ silages. 
Table 3 Carbon dioxide produced $\left(\mathrm{CO}_{2} \mathrm{~g} / \mathrm{kg} \mathrm{DM}\right)$ and $\mathrm{pH}$ of maize cob silages after five days of aerobic exposure $(n=3)$

\begin{tabular}{lcl}
\hline \multirow{2}{*}{ Treatment } & \multicolumn{2}{c}{ Parameters } \\
\cline { 2 - 3 } & $\mathrm{CO}_{\mathbf{2}} \mathbf{~} \mathbf{~} \mathbf{k g} \mathbf{~ D M}$ & $\mathbf{p H}$ \\
\hline CON & $0.7^{\mathrm{a}}$ & 8.2 \\
MOL & $1.5^{\mathrm{b}}$ & 8.3 \\
MOW & $0.9^{\mathrm{a}}$ & 8.3 \\
ENZ1 & $1.6^{\mathrm{b}}$ & 8.3 \\
ENZ2 & $1.4^{\mathrm{b}}$ & 8.3 \\
SEM & 0.12 & 0.04 \\
P-values & 0.002 & 0.550 \\
\hline
\end{tabular}

CON (control, maize cobs with no additives); MOL (maize cobs with $33 \%$ molasses solution only); MOW (maize cobs with 33\% molasses solution and whey); ENZ1 (maize cobs with 33\% molasses solution, whey and enzyme at $0.5 \mathrm{~g} / \mathrm{kg}$ ); ENZ2 (Maize cobs with 33\% molasses solution, whey and enzyme at $1 \mathrm{~g} / \mathrm{kg}$ ). SEM: standard error of mean.

\section{Discussion}

Maize cobs were mixed with water, molasses, whey and exogenous enzymes to reduce DM content, improve the water-soluble carbohydrate content and break down the fibre matrix. The DM for all treatments on day 0 (567 g/kg as fed) was comparable with that reported by Khan et al. (2006) for urea-treated maize cobs. Such a high DM potentially impairs effective ensiling by curtailing the growth of lactic acid bacteria and reducing the rate and extent of fermentation (Ashbell et al., 1991). The low WSC content (8.2 g/kg DM) of the untreated maize cobs pre-ensiling justified the addition of molasses and whey. The other silages (MOL, MOW and ENZ 1 and 2) had WSC contents of $30 \mathrm{~g} / \mathrm{kg} \mathrm{DM}$ and above. The WSC are fermented to lactic acid by epiphytic $L A B$, and a minimal concentration of $30 \mathrm{~g} \mathrm{WSC} / \mathrm{kg}$ DM is critical for successful fermentation (Haigh \& Parker, 1985; Weinberg et al., 1988; Bautista-Trujillo et al., 2009).

The results of this study suggest that molasses, whey and enzymes are not necessary for rapid reduction of $\mathrm{pH}$ when ensiling maize cobs. McDonald et al. (2002) reported that well-preserved silages had a $\mathrm{pH}$ range of 3.8 to 4.2 and only the CON silage attained that. Although the LA production did not differ among treatments, the higher ash in the MOL, MOW, ENZ1 and ENZ2 treatments may have played a buffering role. Kung \& Shaver (2001) reported that CP and ash have high buffering capacity. Molasses contain up to $132 \mathrm{~g} / \mathrm{kg} \mathrm{DM}$ of ash (Xande et al., 2010), while that of whey could be up to $80 \mathrm{~g} / \mathrm{kg} \mathrm{DM}$ (Ben Salem \& Fraj, 2007). Zobell et al. (2004) stated that good silage has lactic acid levels ranging from 30 to140 $\mathrm{g} / \mathrm{kg}$, and those of the present study were lower than that threshold, suggesting poorly fermented silages. This may be attributed to low WSC levels pre-ensiling. This agrees with the findings of Van Nevel et al. (2006), who reported poor in vitro fermentability of maize cobs. Zhang et al. (2010b) stated that a $2: 1$ ratio of lactic acid to acetic acid is an indicator of strong homolactic fermentation. Since the maize cob silage lactate : acetate ratio (LA : AA) was less than $2: 1$, it suggests they underwent hetero-fermentation. A likely explanation is the finding that the addition of molasses to wilted lucerne increased the acetate concentration and decreased the lactate to acetate ratio, as reported by Hashemzadeh-Cigari et al. (2011). However, high concentrations of acetic acid could have been the result of poor compaction and retention of air pockets, a characteristic commonly associated with drier feedstocks such as maize cobs (Kung \& Shaver, 2001). Addition of heterolactic inoculants could decrease the LA : AA ratio and might benefit the ensiling of maize cobs.

There was no increase in CP of the treatments after the addition of molasses and whey in this study, contrary to other reports in which molasses and whey resulted in a positive influence on CP (Migwi et al., 2000; Baytok et al., 2005; Mahala \& Khalifa, 2007). This is surprising because molasses has been reported to have up to $44 \mathrm{~g} \mathrm{CP} / \mathrm{kg}$ DM (Xande et al., 2010), and in whey it ranges from 106 to $130 \mathrm{~g} / \mathrm{kg} \mathrm{DM}$ (Weinberg, 2004; Formigoni et al., 2006; Ben Salem \& Fraj, 2007). In addition, whey has soluble protein, which would significantly complement the mostly insoluble $\mathrm{CP}$ in maize cobs. The low ammonia concentrations observed in this study (average $25 \pm 6.6 \mathrm{~g} \mathrm{NH}_{3}-\mathrm{N} / \mathrm{kg} \mathrm{TN}$ ) are indicative of minimal protein breakdown during the ensiling process. This may be attributed to the low $\mathrm{CP}$ available in the silages, although whey must have contributed some soluble protein. High concentrations of ammonia ( $>12 \%$ to $15 \%$ 
of CP) are a result of excessive protein breakdown caused by a slow drop in pH or clostridial action (Kung \& Shaver, 2001).

The increase in fibre levels at day 32 compared with day 0 , especially for the ENZ2 treatment, suggests enhanced fermentative processes of highly fermentable non-starch polysaccharide components. This would have resulted in recalcitrant components remaining in the samples. The results are supported by reports that cell wall degrading enzymes reduced fibre content in maize forage at ensiling (Sheperd \& Kung, 1996; Meeske et al., 1999; 2002; Colombatto et al., 2004). The extent to which this occurs is difficult to measure accurately because ensiling probably solubilizes part of the non-starch polysaccharide fraction, so that polysaccharides that are recovered in NDF and ADF fractions would differ before and after ensiling, as observed by De Vries et al. (2012).

The aerobic stability study was inconclusive. The $\mathrm{CO}_{2}$ production $(0.7-1.6 \mathrm{~g} / \mathrm{kg} \mathrm{DM})$ obtained in this study is an indication of DM losses and the extent of aerobic stability (McDonald et al., 1991). The aerobic stability of the maize cobs deteriorated with the addition of molasses and enzymes, and stabilized with the addition of whey. Nkosi et al. (2009) obtained higher $\mathrm{CO}_{2}$ values for whole maize crop. However, there were similar increases in $\mathrm{pH}$ in all silages after exposure to air, which is indicative of poor aerobic stability. Ensiling with heterolactic fermentative inoculants could help improve aerobic stability.

\section{Conclusion}

In this study the addition of molasses and whey did not improve the nutritive quality of the maize cobs after ensiling. Further investigations using higher concentrations of whey and molasses may be warranted to improve the energy and protein composition of the maize cobs. Ensiling maize cobs with molasses, whey and exogenous enzymes resulted in lower fibre levels in the maize cobs, which could enhance intake and digestibility of nutrients when offered to pigs as a component of a balanced diet. The aerobic stability of all maize cob silages in this study was poor, and the addition of a heterofermentative inoculant should be investigated. Further work is needed to investigate the effects of ensiling maize cobs on digestibility of nutrients and feed intake.

\section{Acknowledgements}

The authors would like to thank the ARC-API for the funding and use of facilities for the study. Special thanks are also extended to R. Thomas and F. Nherera-Chokuda from the ARC, and S. Ndou from University of KwaZulu-Natal for their assistance in collecting data and proofreading the work.

\section{Authors' contributions}

ATK, BDN and MC were in charge of project design and project implementation. ATK wrote the manuscript. All co-authors participated in collating the results, carrying out statistical analyses, interpreting the study and correcting the manuscript.

\section{Conflict of interest declaration}

We wish to confirm that there are no known conflicts of interest associated with the publication of this manuscript and there has been no significant financial support for this work that could have influenced its outcome. We also confirm that this manuscript has been read and approved by all authors and that the order of authors listed in the manuscript has been approved by all of us.

\section{References}

AOAC, 1990. Official Methods of Analysis. 15th ed. Association of Official Analytical Chemists, Washington DC, USA.

Ashbell, G., Weinberg, Z.G., Azriel, A., Hen, Y. \& Horev, B., 1991. A simple system to study the aerobic deterioration of silages. Can. Agric. Eng. 33, 391-393.

Bautista-Trujillo, G.U., Cobos, M.A., Ventura-Canseco, L.M.C., Ayora-Talavera, T., Abud-Archila, M., Oliva-Llaven, M.A., Dendooven, L. \& Gutierrez-Miceli, F.A., 2009. Effect of sugarcane molasses and whey on silage quality of maize. Asian J. Crop Sci. 1, 34-39.

Baytok, E., Aksu, T., Karsli, M.A. \& Muruz, H., 2005. The effects of formic acid, molasses and inoculant as silage additives on corn silage composition and ruminal fermentation in sheep. Turk. J. Vet. Anim. Sci. 29, 469-474.

Ben-Salem, M. \& Fraj, M., 2007. The effects of feeding liquid whey in the diet of lactating dairy cows on milk production and composition. J. Cell Anim. Biol. 1, 7-10.

Colombatto, D., Mould, F.L., Bhat, M.K., Phipps, R.H. \& Owen, E., 2004. In vitro evaluation of fibrolytic enzymes as additives for maize (Zea mays L.) silage: II. Effects on rate of acidification, fibre degradation during ensiling and rumen fermentation. Anim. Feed Sci. Technol. 111, 111-128.

De Vries, S., Pustjens, A.M., Schols, H.A., Hendriks, W.H. \& Gerrits, W.J.J., 2012. Improving digestive utilization of fiberrich feedstuffs in pigs and poultry by processing and enzyme technologies: A review. Anim. Feed Sci. Technol. 178, 123-138.

Dubois, M., Giles, K.A., Hamilton, J.K., Rebes, P.A. \& Smith, F., 1956. Colorimetric method for determination of sugars and related substances. Anal. Chem. 28, 350-356. 
Ebringerová, A. \& Heinze, T., 2000. Xylan and xylan derivatives - biopolymers with valuable properties 1 . Naturally occurring xylans structures, isolation procedures and properties. Macromol. Rapid Commun. 21, 542-556.

Eun, J.-S. \& Beauchemin, K.A., 2007. Enhancing in vitro degradation of alfalfa hay and corn silage using feed enzymes. J. Dairy Sci. 90, 2839-2851.

Fevrier, C., Bourdon, D. \& Aumaitre, A., 1992. Effects of level of dietary fibre from wheat bran on digestibility of nutrients, digestive enzymes and performance in the European Large White and Chinese Mei Shan pig. J. Anim. Physiol. Anim. Nutr. 68, 60-72.

Formigoni, A., Piva, A., Pezzi, P., Castellani, G. \& Biagi, G., 2006. The influence of feeding fresh liquid whey on some blood metabolites, insulin and cecal fermentations of growing pigs. Anim. Feed Sci. Technol. 131, 52-65.

Gatel, F., Grosjean, F. \& Castaing, J., 1988. Feeding value of ensiled high-moisture maize grain with cob for growingfinishing pigs. Anim. Feed Sci. Technol. 20, 145-153.

Haigh, P.M. \& Parker, J.V.G., 1985. Effect of silage additives and wilting on silage fermentation, digestibility and intake, and on live weight change of young cattle. Grass Forage Sci. 40, 429-436.

Hashemzadeh-Cigari, F., Khorvash, M., Ghorbani, G.R. \& Taghizadeh, A., 2011. The effects of wilting, molasses and inoculants on the fermentation quality and nutritive value of lucerne silage. S. Afr. J. Anim. Sci. 41, 377-388.

Kanengoni, A.T., Dzama, K., Chimonyo, M., Kusina, J. \& Maswaure, S.M., 2004. Growth performance and carcass traits of Large White, Mukota and their $F_{1}$ crosses fed on graded levels of maize cobs. Anim. Sci. 78, 61-66.

Khan, M.A., Iqbal, Z., Sarwar, M., Nisa, M., Khan, M.S., Lee, W.S., Lee, H.J. \& Kim, H.S., 2006. Urea treated corncobs ensiled with or without additives for buffaloes: Ruminal characteristics, digestibility and nitrogen metabolism. Asian Austral. J. Anim. Sci. 19, 705-712.

Kung Jr., L. \& Shaver, R., 2001. Interpretation of silage fermentation analysis report. Focus on Forage 3, 1-5.

Latif, F. \& Rajoka, M.I., 2001. Production of ethanol and xylitol from corn cobs by yeasts. Biores. Technol. 77, 57-63.

Le Gall, M., Warpechowski, M., Jaguelin-Peyraud, Y. \& Noblet, J., 2009. Influence of dietary fibre level and pelleting on the digestibility of energy and nutrients in growing pigs and adult sows. Animal 3, 352-359.

Mahala, A.G. \& Khalifa, I.M., 2007. The effect of molasses levels on quality of sorghum (Sorghum bicolor) silage. Res. J. Anim. Vet. Sci. 2, 43-46.

McDonald, P., Henderson, A.R. \& Heron, S.J.E., 1991. The Biochemistry of Silage. Chalcombe Publications, Marlow, Buckinghamshire, UK. pp. 109.

McDonald, P., Edwards, R.A., Greenhalgh, J.F.D. \& Morgan, C.A., 2002. Animal Nutrition. 6th ed. Longman Scientific and Technical, Prentice Hall, New Jersey, USA.

Meeske, R., Basson, H. \& Cruywagen, C., 1999. The effect of a lactic acid bacterial inoculant with enzymes on the fermentation dynamics, intake and digestibility of digitaria eriantha silage. Anim. Feed Sci. Technol. 81, 237-248.

Meeske, R., Van der Merwe, G.D., Greyling, J.F. \& Cruywagen, C.W., 2002. The effect of adding an enzyme containing lactic acid bacterial inoculant to big round bale oat silage on intake, milk production and milk composition of Jersey cows. Anim. Feed Sci. Technol. 97, 159-167.

Migwi, P.K., Gallagher, J.R. \& Van Barneveld, R.J., 2000. Effect of molasses on the fermentation quality of wheat straw and poultry litter ensiled with citrus pulp. Aust. J. Exp. Agric. 40, 825-829.

Ndindana, W., Dzama, K., Ndiweni, P., Maswaure, S. \& Chimonyo, M., 2002. Digestibility of high fibre diets and performance of growing Zimbabwean indigenous Mukota pigs and exotic Large White pigs fed maize based diets with graded levels of maize cobs. Anim. Feed Sci. Technol. 97, 199-208.

Nkosi, B.D., Meeske, R., Palic, D. \& Langa, T., 2009. Laboratory evaluation of an inoculant for ensiling whole crop maize in South Africa. Anim. Feed Sci. Technol. 150, 144-149.

Porter, M.G. \& Murray, R.S., 2001. The volatility of components of grass silage on oven drying and the inter-relationship between dry matter content estimated by different analytical methods. Grass Forage Sci. 56, 405-411.

Pryce, J.D., 1969. Modification of the Barker \& Summerson method for the determination of lactic acid. Anal. 94, 1151-1152.

Repetto, J.L., Echarri, V., Aguerre, M. \& Cajarville, C., 2011. Use of fresh cheese whey as an additive for lucerne silages: effects on chemical composition, conservation quality and ruminal degradation of cell walls. Anim. Feed Sci. Technol. 170, 160-164.

Rezaei, J., Rouzbehan, Y. \& Fazaeli, H., 2009. Nutritive value of fresh and ensiled amaranth (Amaranthus hypochondriacus) treated with different levels of molasses. Anim. Feed Sci. Technol. 151, 153-160.

SAS, 2012. SAS for Windows. Version 9.3. SAS Inst. Inc., Cary, NC., USA.

Sheperd, A.C. \& Kung Jr., L., 1996. Effects of an enzyme additive on composition of corn silage ensiled at various stages of maturity. J. Dairy Sci. 79, 1767-1773.

Stanogias, G. \& Pearce, G.R., 1985. The digestion of fibre by pigs. The effects of amount and type of fibre on apparent digestibility, nitrogen balance and rate of passage. Br. J. Nutr. 53, 513-530.

Stokes, M.R., 1992. Effects of an enzyme mixture, an inoculant, and their interaction on silage fermentation and dairy production. J. Dairy Sci. 75, $764-773$.

Suzuki, M. \& Lund, C.W., 1980. Improved gas liquid chromatography for simultaneous determination of volatile fatty acids and lactic acid in silage. J. Agric. Food Chem. 28, 1040-1041.

Urriola, P.E., Shurson, G.C. \& Stein, H.H., 2010. Digestibility of dietary fiber in distillers coproducts fed to growing pigs. J. Anim. Sci. 88, 2373-2381.

Van Nevel, C.J., Dierick, N.A., Decuypere, J.A. \& De Smet, S.M., 2006. In vitro fermentability and physicochemical properties of fibre substrates and their effect on bacteriological and morphological characteristics of the gastrointestinal tract of newly weaned piglets. Arch. Anim. Nutr. 60, 477-500. 
Van Soest, P.J., Robertson, J.B. \& Lewis, B.A., 1991. Methods of dietary fiber, neutral detergent fiber, and non-starch polysaccharides in relation to animal nutrition. J. Dairy Sci. 74, 3583-3597.

Vázquez, M.J., Alonso, J.L., Domínguez, H. \& Parajó, J.C., 2006. Enhancing the potential of oligosaccharides from corncob autohydrolysis as prebiotic food ingredients. Ind. Crop Prod. 24, 152-159.

Viljoen, J., 1993. Feed sources - Use and feed tables. In: Pig Production in South Africa. Ed: Kemm, E.H., Irene Animal Production Institute. Agricultural Research Council. Bulletin 427.

Weinberg, Z.G., 2004. Recycling agricultural by-products and residues for animal feeding. Concise Encyclopaedia Bioresour. Technol. 56, 671-677.

Weinberg, Z.G., Ashbell, A. \& Azrieli, A., 1988. The effect of applying lactic acid bacteria at ensilage on the chemical and microbiological composition of vetch, wheat and alfalfa silages. J. Appl. Bacteriol. 64, 1-7.

Xande, X., Archimede, H., Gourdine, J.L., Anais, C. \& Renaudeau, D., 2010. Effects of the level of sugarcane molasses on growth and carcass performance of Caribbean growing pigs reared under a ground sugarcane stalks feeding system. Trop. Anim. Health Prod. 42, 13-20.

Xing, L., Chen, L.J. \& Han, L.J., 2009. The effect of an inoculant and enzymes on fermentation and nutritive value of sorghum straw silages. Bioresour. Technol. 100, 488-491.

Zhang, M. Su, F.W.R., Qi, W. \& He, Z., 2010a. Ethanol production from high dry matter corncob using fed-batch simultaneous saccharification and fermentation after combined pretreatment. Bioresour. Technol. 101, 4959-4964.

Zhang, Y.G., Xin, H.S. \& Hua, J.L., 2010b. Effects of treating whole-plant or chopped rice straw silage with different levels of lactic acid bacteria on silage fermentation and nutritive value for lactating Holsteins. Asian Austral. J. Anim. Sci. 23, 1601-1607.

Zobell, D.R., Okine, E.K., Olson, K.C., Wiedmeier, R.D., Goonewardene, L.A. \& Stonecipher, C., 2004. The feasibility of feeding whey silage and effects on production and digestibility in growing cattle. J. Anim. Vet. Adv. 3, 804-809. 